\title{
KEPENTINGAN AKTIVITI FIZIKAL DALAM MEMBINA PERSONALITI DAN MENINGKATKAN PRESTASI AKADEMIK
}

\author{
Syed Lamsah bin Syed Chear ${ }^{1}$, Mohd Imran bin Mohd² \& Sareena Hanim Hamzah ${ }^{3}$ \\ ${ }^{1}$ Fakulti Pendidikan dan Sains Sosial, Universiti Selangor, Malaysia \\ ${ }^{2}$ Kolej Universiti KPJ, Nilai, Negeri Sembilan \\ ${ }^{3}$ Pusat Sukan, Universiti Malaya, Kuala Lumpur \\ Email: syedlamsah@unisel.edu.my
}

\begin{abstract}
Abstrak
Jurnal Sains Sukan dan Pendidikan Jasmani 7(1): Received: 24 December 2017, Accepted: 19 January 2018 - Kecemerlangan pelajar di institusi pengajian tinggi (IPT) sering kali difokuskan kepada prestasi akademik manakala perkembangan personaliti terpinggir. Objektif kajian ini adalah untuk meninjau faktor-faktor yang mendorong keterlibatan pelajar dalam aktiviti fizikal dan kesan penglibatan tersebut terhadap prestasi akademik dan perkembangan personaliti. Responden terdiri daripada 61 pelajar diploma pelbagai bidang yang mengikuti kursus wajib MPU2412 Sukan selama 14 minggu antara Januari sehingga Mei 2016 di sebuah universiti swasta. Data kajian merupakan maklum balas pelajar yang diperoleh melalui borang soal-selidik yang ditadbir pada minggu akhir semester. Enam dimensi yang dinilai adalah (i) ekspresi diri, (ii) dorongan ibu-bapa, ahli keluarga dan sekolah, (iii) minat, (iv) pengaruh persekitaran dan kemudahan yang disediakan, (v) penglibatan dalam aktiviti kelab dan persatuan, (vi) pengetahuan, dan (vii) motivasi dalaman. Analisis melalui Perisian Statistik Sains Sosial (SPSS V22) mendapati nilai Pearson's R bagi menunjukkan korelasi antara aktiviti fizikal dan prestasi akademik adalah kecil iaitu berbasikal (.258), bertanding (.181), bersenam (.176) dan berlari (.001). Nilai korelasi yang negatif dicatatkan untuk aktiviti bersukan (-.135). Responden bersetuju bahawa aktiviti fizikal adalah penting bagi merangsang keupayaan kognitif iaitu proses pembelajaran serta pembentukan personaliti. Ketiadaan motivasi dalaman menjadi faktor penghad utama keterlibatan pelajar untuk aktif terlibat dengan aktiviti fizikal. Kajian ini mencadangkan agar pihak institusi merangka program lebih terancang dan menambah fasiliti untuk menggalakkan lebih ramai pelajar aktif melakukan aktiviti fizikal kerana ia dijangka dapat meningkatkan prestasi akademik dan membangunkan personaliti.
\end{abstract}

Kata Kunci: aktiviti fizikal, prestasi akademik, pembentukan personaliti 


\title{
THE IMPORTANCE OF PHYSICAL ACTIVITY IN BUILDING PERSONALITY AND IMPROVE ACADEMIC PERFORMANCE
}

\begin{abstract}
Excellence in institutions of higher learning (IHL) very often focused to academic performance while the development of student personalities is marginal. The objective of this study was to explore factors that drive student engagement in physical activity and the impact of the involvement towards academic performance and personality growth. The respondent consists of 61 diploma students from various field of studies at a private university. All of them are taking a compulsory course namely MPU2412 Sports for 14 weeks between January until May 2016. A questionnaire were used to collect data from the students at the last week of the semester. The six dimensions assessed are (i) self-expression, (ii) the role of parents, family members and schools, (iii) interests, (iv) the influence of environment and facilities provided, (v) involvement in clubs and associations activities, (vi) knowledge, and (vii) internal motivation. The data is then analysed using the Statistical Package for Social Science (SPSS) version 22. The research findings reveal that there is a small value of Pearson's $R$ to indicate the linear relationship between student academic performance and their engagement on physical activities which are cycling (.258), competing (.181), exercising (.176) and jogging (.001). The irregular activities in sports negatively impact the learning process. The researcher suggest the negative value for plays sport (-.135) is due to the consequences of unplanned activities as compared to competing which normally received strict supervision, training, guidance and monitoring from the university. The findings also shows that most of the students are realized that physical activities might plays important roles and contribute for the development of their cognitive ability thus might affect their academic performance. However, lack of internal motivation among themselves become the limiting factor for them to actively engage in physical activities. The researcher strongly suggest for the institution to develop better sport and exercise facilities and organized more well planned physical activity program for students with the ultimate aim to improve students' personality and their academic performance.
\end{abstract}

Keywords: physical activities, student personality, academic performance 


\section{PENGENALAN}

Kecemerlangan seseorang khususnya para pelajar sering kali dikaitkan kepada prestasi akademik manakala aspek personaliti terpinggir. Usaha-usaha menghasilkan pelajar cemerlang turut memfokuskan kepada aktiviti bersifat ilmiah baik di sekolah mahu pun di luar waktu persekolahan manakala aktiviti-aktiviti bersifat fizikal seperti bersukan dan seumpamanya dianggap menjejaskan tumpuan pembelajaran. Penyelidikan saintifik bagaimanapun menunjukkan sebaliknya iaitu terdapat hubungan positif antara penglibatan para pelajar dalam aktiviti fizikal, kecergasan, sukan dan rekreasi terhadap prestasi akademik (Donnelly et al., 2016; Donnelly \& Lambourne, 2011; Khan et al., 2012; Muñoz, Sanchez-Bueno \& Vos-Saz, 2017). Santana et al., (2017) dalam usaha menganalisis secara sistematik hubungan antara kecergasan fizikal (PF) kanak-kanak dan remaja terhadap prestasi akademik (AP) telah meneliti 45 artikel saintifik yang diterbitkan antara 1996 sehingga Jun 2016, dan mendapati terdapat bukti kukuh adanya perhubungan positif antara kecergasan kardiorespiratori (CRF) dan kluster kecergasan fizikal (PF) terhadap prestasi akademik (AP).

Kajian-kajian terdahulu melaporkan para atlet di sekolah mencapai gred yang lebih baik (Darling et al., 2005; Eccles \& Barber, 1999; Eitle \& Eitle, 2002; Silliker \& Quirk, 1997), mempunyai aspirasi lebih tinggi mengenai pendidikan dan pekerjaan (Darling et al., 2005; Marsh \& Kleitman, 2002; Otto \& Alwin, 1977; Sabo et al., 1993), meluangkan lebih masa menyiapkan tugasan (Marsh \& Kleitman, 2002) dan mempunyai attitude lebih positif terhadap persekolahan (Darling et al., 2005; Eccles \& Barber, 1999) berbanding bukan atlet. Namun Rees \& Sabia (2010) dalam merumuskan dapatan di atas mengatakan ia tidak dapat ditunjukkan dengan jelas korelasi antara bersukan dengan prestasi akademik sama ada ia berlaku oleh kerana sebab akibat atau sebagai kesan tidak langsung dan pembuktian adalah pada nilai yang kecil. Keeley \& Fox (2009) turut sependapat sedemikian tetapi mereka menegaskan bahawa aktiviti fizikal juga tidak memberi kesan negatif kepada proses pembelajaran. Rasberry et al., (2011) turut melaporkan bahawa kekuatan perhubungan antara aktiviti fizikal dan prestasi akademik adalah pada nilai yang kecil. Setelah menganalisis 43 artikel yang menyentuh topik aktiviti fizikal dan pencapaian akademik, kumpulan pengkaji ini merumuskan bahawa lebih separuh daripada penyelidikan menunjukkan perkaitan positif $(50.5 \%)$ dan hanya nisbah kecil berkorelasi negatif $(1.5 \%)$ manakala selebihnya adalah tidak berkaitan (48\%).

Aktiviti fizikal diketahui mempunyai pengaruh positif terhadap daya tumpuan, keupayaan mengingat dan tingkah laku. Pengurangan masa pembelajaran akademik untuk melakukan aktiviti fizikal tidak memberi kesan kepada pencapaian akademik pelajar. Sebaliknya jika masa melakukan aktiviti fizikal dikurangkan untuk menambah masa pembelajaran didapati ia tidak meningkatkan pencapaian pelajar malah memberi kesan negatif kepada kesihatan. Dapatan kajian sebegini mencadangkan adanya hubungan positif antara aktiviti fizikal dengan peningkatan keupayaan kognitif pelajar (Trudeau \& Shephard, 2008).

Impak pendidikan fizikal dan sukan terhadap matlamat pendidikan adalah luas (Richard \& Mary, 2010). Antaranya adalah (i) pencapaian akademik kekal dan bertambah baik dengan peningkatan pendidikan fizikal, aktiviti fizikal atau sukan, (ii) pertambahan sejam masa pendidikan fizikal mendorong kepada kelancaran proses pembelajaran di dalam kelas, (iii) kemahiran konsep, perhatian dan daya tumpuan pelajar meningkat setelah melakukan aktiviti 
fizikal, (iv) 10 minit aktiviti fizikal terancang semasa kelas dapat memperbaiki tingkah laku positif di dalam kelas sekali gus mendorong kepada peningkatan prestasi akademik, (v) terdapat hubungan positif antara aktiviti fizikal terhadap pelbagai komponen kesihatan mental termasuk kebanggaan diri, kawalan emosi, semangat dan harapan terhadap masa hadapan, dan (vi) perlakuan aktiviti fizikal juga memberi kesan positif terhadap kawalan terhadap rasa bimbang, tertekan, mood dan keterampilan diri. Selain daripada itu penglibatan remaja dalam aktiviti fizikal dikatakan mampu membina nilai-nilai positif lain seperti kepimpinan, kesukarelawan dan kenegaraan.

Daripada sumber-sumber ilmiah di atas dapat dirumuskan bahawa aktiviti fizikal meningkatkan keupayaan kognitif, tingkah laku positif serta prestasi akademik. Maka timbul persoalan, apakah faktor-faktor yang menjadi dorongan dan kekangan kepada pelajar untuk terlibat dengan aktiviti fizikal?

\section{Objektif Kajian}

Objektif kajian ini adalah untuk meninjau tahap penglibatan pelajar dalam aktiviti fizikal, kefahaman mereka mengenai kepentingan aktiviti fizikal terhadap proses pembentukan personaliti dan pencapaian akademik serta faktor-faktor yang menjadi pendorong atau penghad kepada pelajar untuk terlibat dengan aktiviti fizikal.

\section{Soalan kajian}

Soalan-soalan yang ingin dijawab melalui kajian ini adalah:

(i) Bagaimanakah tahap penglibatan para pelajar dalam aktiviti fizikal?

(ii) Apakah faktor-faktor yang menjadi dorongan dan penghad penglibatan pelajar dalam aktiviti fizikal?

\section{Kepentingan Kajian}

Adalah diharapkan rumusan daripada kajian ini dapat digunakan sebagai rujukan untuk membantu pihak berkepentingan terutamanya di peringkat institusi untuk membuat perancangan bagi meningkatkan budaya bersukan di kalangan warga kampus, menyediakan fasiliti dan program-program yang berupaya membentuk personaliti, meningkatkan keupayaan kognitif pelajar seterusnya kecemerlangan akademik mereka.

\section{METODOLOGI}

Data kajian diperoleh menggunakan borang soal-selidik yang diedarkan kepada para pelajar yang mengikuti kursus MPU2412 Sukan. Para pelajar diberi peluang mengemukakan soalansoalan untuk mendapatkan penjelasan daripada pengkaji mengenai kehendak-kehendak setiap soalan. Kaedah kutipan data yang terkawal sebegini sangat penting untuk memastikan responden iaitu para pelajar memberikan maklum balas setepat yang mungkin khususnya bagi 
soalan-soalan yang bersifat terbuka. Pengkaji menggunakan kaedah terkawal ini agar dapat menjelaskan terma-terma tertentu yang mungkin mengelirukan seperti maksud "tidak pernah, kadang-kadang, kerap kali, selalu" dan sebagainya yang terdapat dalam borang soal-selidik. Temu bual dan perbincangan dengan beberapa pegawai di Bahagian Hal Ehwal Pelajar adalah untuk mendapatkan maklumat-maklumat yang berkaitan.

\section{Responden}

Responden terdiri daripada 61 pelajar program Diploma daripada pelbagai bidang yang mendaftar kursus MPU2412 Sukan bagi tempoh pembelajaran selama 14 minggu antara Januari - Mei 2016. Kursus MPU2412 Sukan merupakan kursus wajib IPT yang ditawarkan di setiap semester. Kumpulan pelajar ini dipilih adalah berdasarkan kepada rasional kecenderungan mereka terhadap aspek kecergasan fizikal dan kesukanan apabila mereka memilih kursus ini kerana mereka mempunyai pilihan untuk mengikuti pelbagai kursus lain yang turut ditawarkan. Pengkaji berpendapat responden yang dipilih dapat mewakili populasi pelajar diploma di atas beberapa faktor iaitu (i) kursus ini adalah kursus wajib yang ditawarkan secara terbuka kepada semua pelajar, (ii) pelajar yang mengikuti kursus ini terdiri daripada pelajar daripada pelbagai bidang pengajian, dan (iii) tiada pra-syarat dikenakan kepada pelajar untuk mengikuti kursus ini.

\section{Instrumen Kajian}

Pengumpulan data kajian adalah menggunakan borang soal-selidik yang dibahagi kepada tiga bahagian. Bahagian A dan B adalah mengenai latar belakang responden dan reka bentuk soalan-soalan adalah terbuka untuk mendapatkan jawapan bebas daripada responden. Bahagian $\mathrm{C}$ disediakan secara komprehensif dengan soalan-soalan berbentuk tertutup untuk menyelidik latar belakang penglibatan pelajar terhadap aktiviti fizikal dan menilai kefahaman mereka terhadap aktiviti fizikal, pembentukan personaliti dan prestasi akademik.

Bahagian A dan B membekalkan maklumat pelajar iaitu tahap pengajian dan prestasi akademik yang diukur berdasarkan nilai kumulatif purata gred (CGPA). Beberapa soalan terbuka menyentuh tentang profil diri khususnya penglibatan dalam aktiviti fizikal. Bahagian $\mathrm{C}$ adalah soal-selidik berkaitan pengalaman pembelajaran yang diolah berdasarkan kepada (a) faktor-faktor yang mendorong penglibatan dalam aktiviti fizikal, dan (b) kefahaman pelajar terhadap kepentingan melakukan aktiviti fizikal dan kaitannya kepada pembentukan personaliti dan prestasi akademik. Soalan-soalan dibahagikan kepada tujuh komponen iaitu:

(i) Ekspresi diri (soalan 1-4)

(ii) Peranan ibu-bapa, keluarga dan sekolah (soalan 5 - 8)

(iii) Minat (soalan 9-12)

(iv) Faktor persekitaran dan kemudahan yang disediakan (soalan 13 - 16)

(v) Penglibatan dalam aktiviti kelab dan persatuan (soalan 17 - 24)

(vi) Kefahaman tentang kepentingan bersukan $(25-32)$

(vii) Motivasi/ Halangan dalaman (33 - 36) 
Setiap soalan diberikan lima pilihan jawapan berbentuk skala ordinal untuk menunjukkan kedudukan secara relatif bagi setiap pilihan jawapan yang dibuat iaitu Sangat Tidak Setuju (STS), Tidak Setuju (TS), Tidak Pasti (TP), Setuju (S) dan Sangat Setuju (SS). Analisis Cronbach's Alpha memberikan nilai 0.882 iaitu satu nilai kebolehpercayaan yang boleh diterima bagi instrumen ini. Nilai Alpha Cronbach yang tinggi menunjukkan semua item mengukur satu konstruk dengan satu dimensi yang sama (Gliem \& Gliem, 2003).

\section{DAPATAN KAJIAN DAN PERBINCANGAN}

\section{i. Profil Responden}

Lebih daripada separuh responden terdiri daripada pelajar tahun akhir (55.8\%), manakala tahun pertama (21.3\%) dan tahun kedua (22.9\%). Pencapaian akademik responden adalah agak baik iaitu 39.3\% mencapai CGPA > 3.00, 40.9\% > 2.50 dan selebihnya di bawah 2.50 CGPA. Analisis Pearson's R (-.029) dan Spearman Correlation (-.028) untuk mencari perkaitan antara aktiviti bersukan semasa bersekolah dan pencapaian akademik ketika ini memberikan nilai negatif menunjukkan penglibatan pelajar dalam aktiviti sukan semasa bersekolah tidak memberi impak kepada pencapaian akademik semasa menuntut di universiti. Dapatan kajian ini tidaklah membimbangkan kerana sampel ini terlalu kecil berbanding populasi. Tambahan pula keputusan kajian-kajian lalu hanya membandingkan aktiviti dan prestasi semasa. Fokus kajian ini lebih menjurus kepada usaha untuk mengupas isu-isu yang berkaitan dengan keterlibatan pelajar dengan aktiviti fizikal semasa menuntut di universiti.

Analisis lanjutan mengenai aktiviti pelajar semasa berada di universiti dan prestasi akademik memberikan nilai yang lebih baik (Jadual 1). Terdapat perkaitan pada nilai yang kecil antara penglibatan pelajar dalam aktiviti fizikal iaitu bersenam, berjoging, berbasikal dan bertanding dengan prestasi akademik. Aktiviti bersukan yang tidak terancang mungkin menjadi penyebab kepada kejatuhan prestasi akademik berbanding penglibatan pelajar untuk bertanding kerana lazimnya aktiviti-aktiviti yang bersifat pertandingan sama ada mewakili persatuan, kelab mahupun universiti di dalam atau luar universiti adalah berjadual, dipantau dan diselia dengan baik oleh pegawai-pegawai dan jabatan-jabatan yang berkaitan.

Jadual 1 Hubungan aktiviti fizikal dan prestasi akademik melalui analisis Pearson's R dan Spearman

\begin{tabular}{lccccc}
\hline \multicolumn{1}{c}{ Nilai } & $\begin{array}{c}\text { Bersenam } \\
10 \mathrm{~min}\end{array}$ & $\begin{array}{c}\text { Berjoging } \\
>1 \mathrm{~km}\end{array}$ & $\begin{array}{c}\text { Aktiviti Fizikal } \\
\text { Berbasikal } \\
>15 \mathrm{~min}\end{array}$ & Bersukan & Bertanding \\
\hline Pearson's R & .176 & .001 & .258 & -.135 & .181 \\
Spearman Correlation & .218 & .064 & .238 & -.100 & .197 \\
\hline
\end{tabular}

Nilai Pearson's R dan Spearman Correlation yang rendah dikaitkan kepada tahap penglibatan pelajar yang tidak begitu aktif seperti ditunjukkan di Rajah 1 di bawah. Para pelajar sama ada di Tahun 1, Tahun 2 atau Tahun 3 didapati sebilangan besarnya hanya "kadangkadang" terlibat dalam aktiviti fizikal sama ada bersenam, berjoging atau berbasikal. Pada 
masa yang sama jumlah pelajar yang terlibat dengan aktiviti bercirikan pertandingan adalah terlalu kecil.

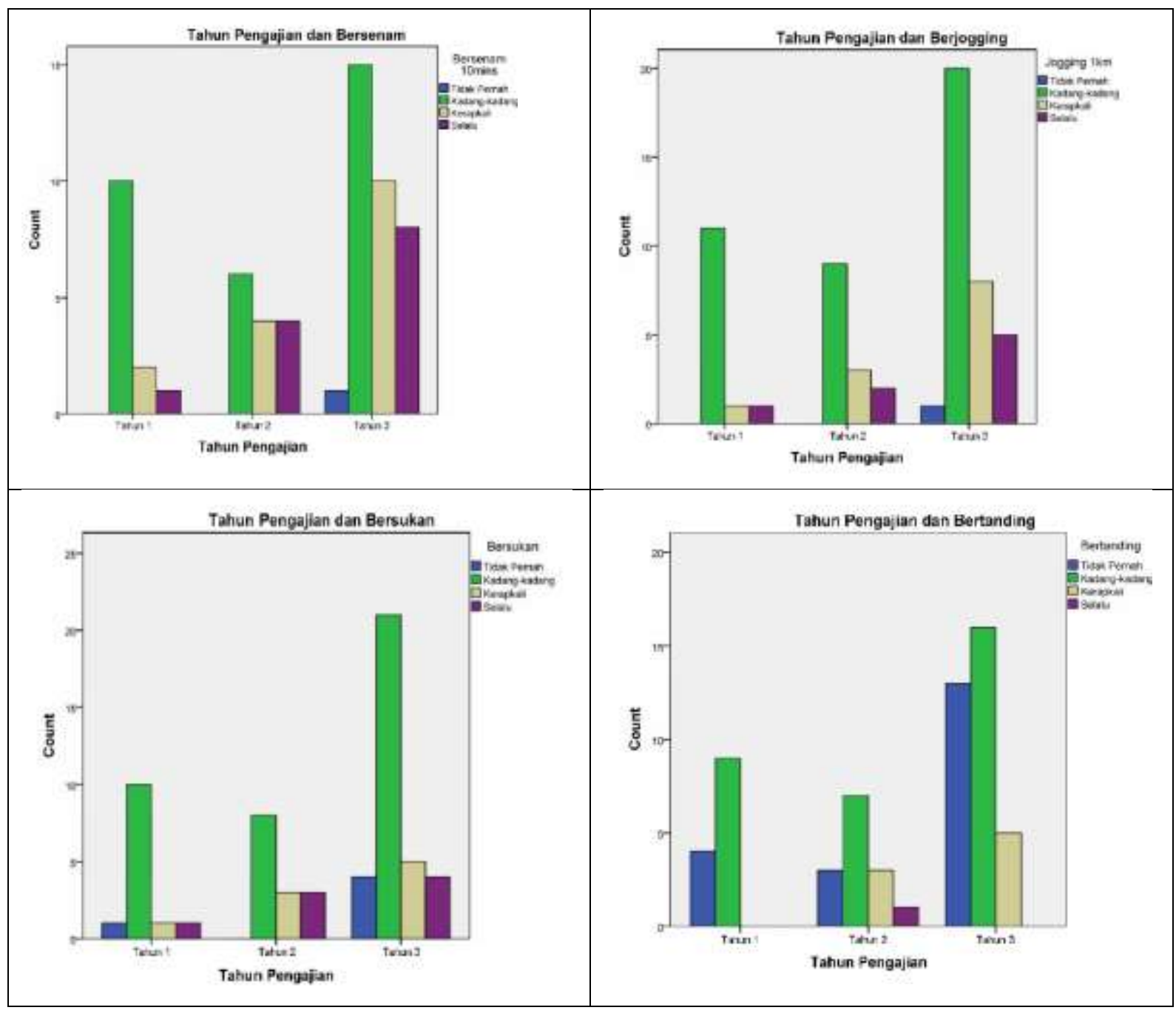

Rajah 1 Kekerapan pelajar terlibat dengan aktiviti fizikal

\section{ii. Kecenderungan pelajar terlibat dalam aktiviti fizikal}

Radar kecenderungan responden untuk terlibat dengan aktiviti fizikal ditunjukkan di Rajah 2 manakala data terperinci di Lampiran A. Analisis data adalah berdasarkan dua perspektif iaitu membincangkan faktor dalaman dan luaran yang dianggap mendorong pelajar terlibat dengan aktiviti fizikal. Faktor dalaman adalah ekspresi diri, minat, pengetahuan dan motivasi manakala faktor luaran merujuk kepada peranan ibu-bapa, keluarga dan sekolah, rangsangan persekitaran dan pengalaman lalu terlibat dengan aktiviti berpersatuan/kelab.

Pada skala $1-5$, para pelajar didapati mempunyai pengetahuan yang baik bahawa aktiviti fizikal mempunyai peranan tersendiri untuk membentuk personaliti dan keupayaan kognitif yang akhirnya mendorong kepada pencapaian akademik (4.42). Para pelajar mempunyai tahap baik bagi ekspresi diri (4.06) dan minat (3.86) tetapi mempunyai tahap 
motivasi dalaman yang sederhana (3.45). Analisis terhadap faktor-faktor luaran pula mendapati para pelajar memiliki tahap baik bagi aspek dorongan ibu-bapa/ keluarga/sekolah (3.91) dan pendedahan kepada aktiviti fizikal (3.77) tetapi agak sederhana bagi aspek pengalaman terlibat dengan aktiviti berpersatuan/kelab (3.64).

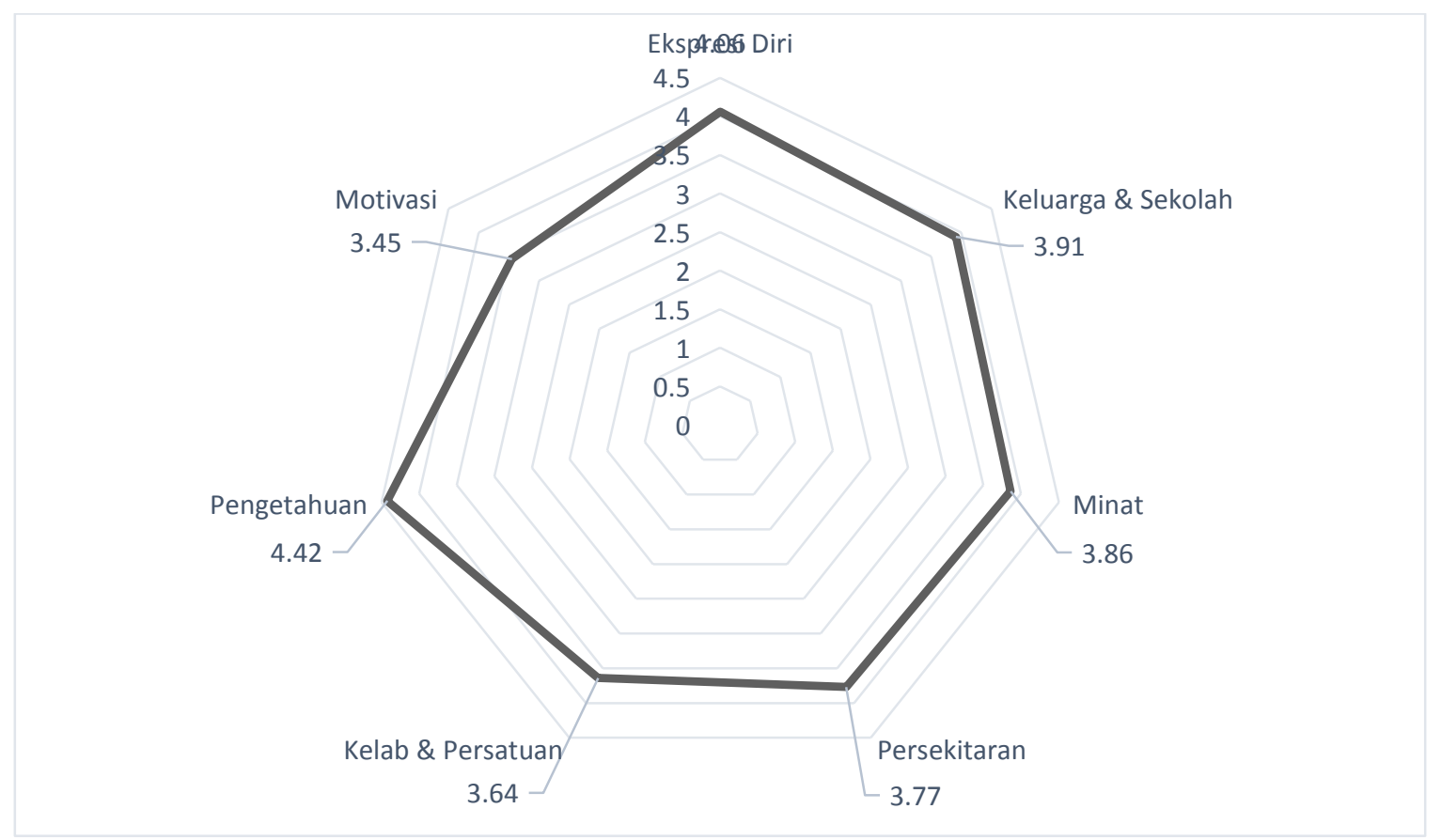

Rajah 2 Radar faktor dorongan penglibatan pelajar terhadap aktiviti fizikal

Amnya berdasarkan aspek 'ekspresi diri' didapati lebih separuh daripada responden beranggapan mereka mempunyai tubuh badan yang sihat dan cergas $(64.0 \%)$, bebas daripada kecederaan (68.8\%), tidak bergantung kepada ubat-ubatan $(80.3 \%)$ dan majoriti besar tidak menghadapi kesukaran melakukan aktiviti seharian (93.4\%) serta turut meluangkan masa bersama-sama rakan melakukan kegiatan rekreasi (90.2\%). Dalam tempoh persekolahan, mereka mendapat dorongan daripada ibu-bapa, keluarga dan sekolah (65.5\%). Dapatan kajian ini selari dengan rumusan oleh Ventura \& Birch (2008) dan Trudeau \& Shephard (2008) yang menyatakan bahawa sokongan sosial penting untuk menggalakkan remaja khususnya perempuan untuk melibatkan diri dengan aktiviti fizikal sekali gus mengurangkan tingkah laku yang tidak diingini. Perbandingan keaktifan pelajar antara jantina kemungkinan menyamai dapatan kajian oleh Bergier, Tsos \& Bergier (2014) yang mencatatkan bahawa terdapat jurang besar antara pelajar lelaki berbanding perempuan, dan pelajar yang tinggal di kawasan luar bandar lebih aktif berbanding mereka yang tinggal di bandar tetapi tiada perkaitan ditunjukkan antara tahap keaktifan pelajar dengan ukuran indeks badan mereka (BMI).

Pengakuan pelajar iaitu memiliki ahli sukan sebagai idola $(60.7 \%)$, menonton TV rancangan sukan $(78.7 \%)$, mengambil tahu berita-berita sukan serta $(73.8 \%)$ bermain sukan yang mereka minati $(88.6 \%)$ dan ini menunjukkan bahawa mereka mempunyai 'minat' terhadap aktiviti fizikal, bersukan atau seumpama. Sebilangan besar pelajar mengakui bahawa 
mereka mempunyai masa untuk melakukan aktiviti fizikal (83.6\%) dan bersetuju terdapat kemudahan sukan disediakan $(63.9 \%)$ dan ianya adalah selamat (63.9\%). Namun begitu hanya separuh daripada kumpulan pelajar ini $(55.7 \%)$ dikelilingi oleh rakan-rakan yang aktif bersukan atau melakukan aktiviti fizikal. Dapatan kajian menyokong kajian terdahulu oleh Deliens et al., (2015) yang merumuskan bahawa faktor minat dan pendedahan kepada persekitaran positif seperti imej universiti, kampus kediaman, gaya hidup, fasiliti yang disediakan, peranan media serta tekanan terhadap peperiksaan adalah saling berkaitan bagi menggalakkan pelajar aktif melakukan aktiviti fizikal. Kumpulan pengkaji ini turut mencadangkan agar lebih kemudahan dan program berkaitan rekreasi dan sukan dianjurkan di universiti termasuk menawarkan kursus-kursus di dalam kurikulum pengajian sebagai strategi untuk mengurangkan tingkah laku yang tidak diingini di kalangan pelajar.

Lebih daripada separuh pelajar $(65.5 \%)$ menyatakan mereka berminat untuk terlibat dengan aktiviti-aktiviti kokurikulum seperti berpersatuan, kelab, sukan dan permainan namun peratusan tersebut berkurang $(54.1 \%)$ apabila dikaitkan dengan kesediaan mereka untuk terlibat. Petunjuk ini selaras dengan dapatan bahawa terdapat sekelompok besar pelajar yang tidak pasti boleh mengelola aktiviti (60.6\%) dan memimpin (62.3\%) kelab dan persatuan. Yang baiknya terdapat peratusan tinggi jumlah pelajar $(86.9 \%)$ bersetuju bahawa mereka mendapat pengalaman berguna apabila terlibat dengan aktiviti kelab dan persatuan serta kegiatankegiatan fizikal, dan peratusan yang agak besar (77.1\%) menyatakan peribadi dan personaliti mereka bertambah baik setelah terlibat dengan aktiviti-aktiviti tersebut.

Pengetahuan responden terhadap kepentingan aktiviti fizikal adalah baik. Para pelajar menyedari bahawa aktiviti fizikal memberi faedah iaitu mengawal berat badan (95.1\%), meningkatkan keyakinan bagi penampilan di khalayak $(88.5 \%)$, pencegahan penyakit dan penjagaan kesihatan (98.3\%). Mereka turut bersetuju bahawa bersukan penting untuk tujuan bersosial (93.5\%) dan pembinaan personaliti diri yang unggul (96.7\%). Lebih penting lagi para pelajar menyedari bersukan dapat meningkatkan daya tumpuan (95.1\%) dan kebolehan untuk merancang strategi (90.2\%) iaitu kemahiran-kemahiran kognitif yang dapat dikaitkan kepada keupayaan untuk mencapai prestasi akademik yang lebih baik (81.9\%). Pemerhatian lebih terperinci boleh dirujuk kepada Sirard, Pfeiffer \& Pate (2006) dan Kondrič et al., (2013) yang mendapati bahawa pelajar lelaki lebih cenderung kepada aktiviti fizikal yang bersifat pertandingan manakala perempuan didorong oleh tujuan bersosial dan kecergasan. Individu yang aktif juga cenderung untuk mempamerkan gaya hidup sihat yang lain seperti memakan buah-buahan dan tidak merokok berbanding individu yang tidak aktif yang lebih cenderung menonton TV dan menggunakan alkohol (Romaguera et al., 2011).

Dapatan kajian seperti di atas menggambarkan bahawa para pelajar mempunyai kelapangan dan berminat dengan aktiviti fizikal dan kesukanan. Mereka juga menyedari aktiviti fizikal dan bersukan penting dan membawa banyak faedah. Dapatan ini bagaimanapun bertentangan dengan maklumat daripada Rajah 1 yang menunjukkan mereka tidak begitu aktif melakukan aktiviti fizikal dan bersukan. Analisis lanjut menunjukkan para pelajar didapati mempunyai faktor halangan dalaman yang agak tinggi (motivasi dalaman yang rendah). Mereka perlukan dorongan (70.4\%), tidak dapat melakukan aktiviti fizikal secara berseorangan (62.3\%) sehinggakan berpendapat aktiviti fizikal seperti bersukan dan seumpamanya itu perlu diwajibkan (63.9\%). Situasi sebegini tidaklah mengejutkan kerana faktor kurangnya motivasi 
dalaman dikenal pasti menjadi faktor kekangan penglibatan pelajar terhadap aktiviti fizikal selain ketiadaan jurulatih dan batasan masa (Sirard, Pfeiffer \& Pate, 2006; Abdullah et al., 2005) selain kurangnya sokongan daripada rakan sebaya (Hohepa, Schofield \& Kolt, 2006).

\section{Kesimpulan}

Penglibatan kumpulan pelajar di sebuah universiti swasta yang dikaji terhadap aktiviti fizikal adalah sederhana. Terdapat perkaitan pada nilai yang kecil antara keaktifan bersenam, berjoging, berbasikal dan bertanding dengan prestasi akademik. Nilai negatif perkaitan antara bersukan dengan prestasi akademik mencadangkan supaya pihak institusi mengambil langkah proaktif untuk mendedahkan para pelajar mengenai amalan baik untuk bersukan seperti pengurusan masa, pemakanan dan seumpamanya supaya aktiviti tersebut tidak memberi kesan negatif kepada proses pembelajaran.

Berdasarkan analisis tujuh faktor dorongan untuk melakukan aktiviti fizikal didapati kumpulan pelajar yang dinilai mempunyai ekspresi diri yang positif, berminat, mendapat dorongan daripada ibu-bapa, keluarga dan sekolah serta terdedah kepada persekitaran positif di universiti. Namun penglibatan mereka terhadap pelbagai aktiviti fizikal sama ada bersenam, berjoging, bersukan dan menyertai pertandingan adalah sederhana. Situasi ini mungkin disebabkan mereka kurang terdedah dengan aktiviti berpersatuan/kelab (sekali gus mengurangkan peluang untuk bersosial dan rangkaian untuk melakukan aktiviti fizikal) serta kurangnya motivasi dalaman untuk menguatkan azam diri bagi melakukan aktiviti fizikal. Didapati para pelajar memerlukan dorongan daripada rakan-rakan dan faktor tarikan lain dan situasi ini mencadangkan supaya pihak institusi merangka secara terancang program-program yang melibatkan aktiviti secara berkumpulan di pelbagai peringkat secara berterusan untuk membudayakan aktiviti bersukan di kalangan pelajar. Penawaran kursus berkaitan perlu diperluaskan kepada semua pelajar agar mereka mendapat pengetahuan dan kemahiran yang diperlukan bagi memastikan matlamat untuk membentuk personaliti diri dan peningkatan pencapaian akademik tercapai.

\section{RUJUKAN}

Abdullah, A. S. M., Wong, C. M., Yam, H. K., \& Fielding, R. (2005). Factors related to nonparticipation in physical activity among the students in Hong Kong. International Journal of Sports Medicine, 26(7): 611-615.

Bergier, B., Tsos, A., \& Bergier, J. (2014). Factors determining physical activity of Ukrainian students. Annals of Agricultural and Environmental Medicine, 21(3): 613-616.

Darling, N., Caldwell, L. L., \& Smith, R. (2005). Participation in school-based extracurricular activities and adolescent adjustment. Journal of Leisure Research, 37(1): 51-56.

Donnelly, J. E., Hillman, C. H., Castelli, D., Etnier, J. L., Lee, S., Tomporowski, P., Szabo-Reed, A. N. (2016). Physical Activity, Fitness, Cognitive Function, and Academic Achievement in Children: A Systematic Review. Medicine \& Science in Sports \& Exercise, 48(6): 1197-1222.

Donnelly, J. E., \& Lambourne, K. (2011). Classroom-based physical activity, cognition, and academic achievement. Preventive Medicine, 52 (SUPPL). 
Eccles, J. S., \& Barber, B. L. (1999). Student council, volunteering, basketball, or marching band: What kind of extracurricular involvement matters? Journal of Adolescent Research, 14(1): 10-43.

Eitle, T. M., \& Eitle, D. J. (2002). Race, cultural capital, and the educational effects of participation in sports. Sociology of Education, 75(April (2)): 123-146.

Gliem J.A. \& Gliem R.A. (2003). Calculating, Interpreting and Reporting Cronbach's Alpha Reliability Coefficient for Likert-Type Scales. Midwest Research to Practice Conference in Adult, Continuing, and Community Education. Muat turun pada 21 Disember 2017 daripada s3.spanglefish.com/s/8287/documents/.../cronbach\%20alpha.pdf

Hohepa, M., Schofield, G., \& Kolt, G. S. (2006). Physical Activity: What Do High School Students Think? Journal of Adolescent Health, 39(3): 328-336.

Keeley, T. J. H., \& Fox, K. R. (2009). The impact of physical activity and fitness on academic achievement and cognitive performance in children. International Review of Sport and Exercise Psychology, 2: 198 - 214.

Khan, M. Y., Jamil, A., Khan, U. A., \& Kareem, U. (2012). Association between participation in sports and academic achievement of college students. Business and Social Sciences, 2(8), 419-431.

Kondrič, M., Sindik, J., Furjan-Mandić, G., \& Schiefler, B. (2013). Participation motivation and student's physical activity among sport students in three countries. Journal of Sports Science and Medicine, 12(1): 10-18.

Marsh, H. W., \& Kleitman, S. (2002). Extracurricular school activities: The good, the bad and the nonlinear. Harvard Educational Review, 72(4): 464-514.

Muñoz-Bullón, F., Sanchez-Bueno, M. J., \& Vos-Saz, A. (2017). The influence of sports participation on academic performance among students in higher education. Sport Management Review, 20(4), 365-378.

Otto, L. B., \& Alwin, D. F. (1977). Athletics, aspirations, and attainments. Sociology of Education, 50(April (2)): 102-113.

Rasberry, C. N., Lee, S. M., Robin, L., Laris, B. A., Russell, L. A., Coyle, K. K., \& Nihiser, A. J. (2011). The association between school-based physical activity, including physical education, and academic performance: A systematic review of the literature. Preventive Medicine, 52: 10 - 20.

Rees, D. I., \& Sabia, J. J. (2010). Sports participation and academic performance: Evidence from the National Longitudinal Study of Adolescent Health. Economics of Education Review, 29(5): 751-759.

Romaguera, D., Tauler, P., Bennasar, M., Pericas, J., Moreno, C., Martinez, S., \& Aguilo, A. (2011). Determinants and patterns of physical activity practice among Spanish university students. Journal of Sports Sciences, 29(9): 989-997.

Sabo, D., Melnick, M. J., \& Vanfossen, B. E. (1993). High school athletic participation and postsecondary educational and occupational mobility: A focus on race and gender. Sociology of Sport Journal, 10(1): 44-56.

Santana, C. C. A., Azevedo, L. B., Cattuzzo, M. T., Hill, J. O., Andrade, L. P., \& Prado, W. L. (2017). Physical fitness and academic performance in youth: A systematic review. Scandinavian Journal of Medicine and Science in Sports, 27: 579 - 603.

Silliker, S. A., \& Quirk, J. T. (1997). The effect of extracurricular activity participation on the academic performance of male and female high school students. School Counselor, 44(4): 288-294.

Sirard, J. R., Pfeiffer, K. A., \& Pate, R. R. (2006). Motivational factors associated with sports program participation in middle school students. Journal of Adolescent Health, 38(6), 696-703.

Trudeau, F., \& Shephard, R. J. (2008). Physical education, school physical activity, school sports and academic performance. International Journal of Behavioral Nutrition and Physical Activity, 5, 12.

Ventura, A. K., \& Birch, L. L. (2008). Does parenting affect children's eating and weight status? International Journal of Behavioral Nutrition and Physical Activity, Vol (5). 


\section{Lampiran A}

\begin{tabular}{|c|c|c|c|c|c|c|c|c|}
\hline \multicolumn{9}{|c|}{ Ekspresi pelajar terhadap kesihatan dan keterampilan diri } \\
\hline \multirow[t]{2}{*}{ No. } & \multirow[t]{2}{*}{ Pernyataan } & \multicolumn{5}{|c|}{ Peratusan $(\%)$} & \multirow[t]{2}{*}{ Mean } & \multirow{2}{*}{$\begin{array}{c}\text { Std. } \\
\text { Deviation }\end{array}$} \\
\hline & & STS & TS & TP & $\mathrm{S}$ & SS & & \\
\hline 1 & $\begin{array}{l}\text { Saya memiliki tubuh badan yang sihat } \\
\text { dan cergas. }\end{array}$ & 0.0 & 1.6 & 34.4 & 44.3 & 19.7 & 3.82 & .764 \\
\hline 2 & $\begin{array}{l}\text { Anggota tubuh badan saya bebas } \\
\text { daripada kecederaan. }\end{array}$ & 0.0 & 4.9 & 26.2 & 37.7 & 31.1 & 3.95 & .884 \\
\hline 3 & $\begin{array}{l}\text { Saya tidak bergantung kepada } \\
\text { suplemen. }\end{array}$ & 3.3 & 8.2 & 8.2 & 31.1 & 49.2 & 4.15 & 1.093 \\
\hline 4 & $\begin{array}{l}\text { Saya dapat melakukan aktiviti-aktiviti } \\
\text { fizikal dalam kehidupan seharian. }\end{array}$ & 0.0 & 1.6 & 4.9 & 50.8 & 42.6 & 4.34 & .655 \\
\hline \multicolumn{9}{|c|}{ Faktor ibu-bapa, keluarga dan sekolah berkaitan aktiviti fizikal } \\
\hline \multirow[t]{2}{*}{ No. } & \multirow[t]{2}{*}{ Pernyataan } & \multicolumn{5}{|c|}{ Peratusan $(\%)$} & \multirow[t]{2}{*}{ Mean } & \multirow{2}{*}{$\begin{array}{c}\text { Std. } \\
\text { Deviation }\end{array}$} \\
\hline & & STS & TS & TP & $\mathrm{S}$ & SS & & \\
\hline 5 & $\begin{array}{l}\text { Saya melakukan aktiviti fizikal } \\
\text { bersama ibu-bapa. }\end{array}$ & 6.6 & 9.8 & 29.5 & 37.7 & 16.4 & 3.48 & 1.089 \\
\hline 6 & $\begin{array}{l}\text { Saya mendapat dorongan daripada adik } \\
\text { beradik untuk melakukan pelbagai } \\
\text { aktiviti luar rumah. }\end{array}$ & 3.3 & 11.5 & 19.7 & 47.5 & 18.0 & 3.66 & 1.015 \\
\hline 7 & $\begin{array}{l}\text { Saya dan rakan-rakan meluangkan } \\
\text { masa untuk aktiviti sukan dan rekreasi. }\end{array}$ & 1.6 & 1.6 & 6.6 & 49.2 & 41.0 & 4.26 & .794 \\
\hline 8 & $\begin{array}{l}\text { Guru-guru memberi galakkan untuk } \\
\text { terlibat dengan aktiviti sukan/rekreasi. }\end{array}$ & 0.0 & 3.3 & 11.5 & 44.3 & 41.0 & 4.23 & .783 \\
\hline \multicolumn{9}{|c|}{ Petunjuk-petunjuk minat terhadap aktiviti kesukanan di kalangan pelajar } \\
\hline \multirow[t]{2}{*}{ No. } & \multirow[t]{2}{*}{ Pernyataan } & \multicolumn{5}{|c|}{ Peratusan $(\%)$} & \multirow[t]{2}{*}{ Mean } & \multirow{2}{*}{$\begin{array}{c}\text { Std. } \\
\text { Deviation }\end{array}$} \\
\hline & & STS & $\mathrm{TS}$ & $\mathrm{TP}$ & $\mathrm{S}$ & $\mathrm{SS}$ & & \\
\hline 9 & $\begin{array}{l}\text { Saya mempunyai seorang ahli sukan } \\
\text { sebagai idola. }\end{array}$ & 8.2 & 14.8 & 16.4 & 45.9 & 14.8 & 3.44 & 1.162 \\
\hline 10 & $\begin{array}{l}\text { Saya menonton tv rancangan sukan } \\
\text { yang diminati. }\end{array}$ & 4.9 & 6.6 & 9.8 & 44.3 & 34.4 & 3.97 & 1.080 \\
\hline 11 & $\begin{array}{l}\text { Saya mengambil tahu perihal sukan } \\
\text { yang diminati. }\end{array}$ & 3.3 & 8.2 & 14.8 & 50.8 & 23.0 & 3.82 & .992 \\
\hline 12 & $\begin{array}{l}\text { Saya berpeluang bermain sukan yang } \\
\text { diminati. }\end{array}$ & 1.6 & 1.6 & 8.2 & 52.5 & 36.1 & 4.20 & .792 \\
\hline \multicolumn{9}{|c|}{ Pengaruh persekitaran terhadap keaktifan pelajar dalam aktiviti fizikal } \\
\hline \multirow[t]{2}{*}{ No. } & \multirow[t]{2}{*}{ Pernyataan } & \multicolumn{5}{|c|}{ Peratusan $(\%)$} & \multirow[t]{2}{*}{ Mean } & \multirow{2}{*}{$\begin{array}{c}\text { Std. } \\
\text { Deviation }\end{array}$} \\
\hline & & STS & $\mathrm{TS}$ & $\mathrm{TP}$ & $\mathrm{S}$ & $\mathrm{SS}$ & & \\
\hline 13 & $\begin{array}{l}\text { Saya mempunyai masa untuk } \\
\text { melakukan aktiviti fizikal. }\end{array}$ & 0.0 & 0.0 & 16.4 & 55.7 & 27.9 & 4.11 & .661 \\
\hline 14 & Terdapat kemudahan sukan disediakan. & 3.3 & 1.6 & 31.1 & 45.9 & 18.0 & 3.74 & .893 \\
\hline 15 & $\begin{array}{l}\text { Ramai orang sekeliling melakukan } \\
\text { aktiviti fizikal. }\end{array}$ & 1.6 & 14.8 & 27.9 & 37.7 & 18.0 & 3.56 & 1.009 \\
\hline 16 & $\begin{array}{l}\text { Kemudahan sukan yang disediakan } \\
\text { selamat. }\end{array}$ & 3.3 & 3.3 & 29.5 & 47.5 & 16.4 & 3.70 & .901 \\
\hline \multicolumn{9}{|c|}{ Penglibatan pelajar dalam aktiviti persatuan, kelab dan sukan } \\
\hline \multirow[t]{2}{*}{ No. } & \multirow[t]{2}{*}{ Pernyataan } & \multicolumn{5}{|c|}{ Peratusan $(\%)$} & \multirow[t]{2}{*}{ Mean } & Std. \\
\hline & & STs & TS & $\mathrm{TP}$ & $\mathrm{S}$ & SS & & Deviation \\
\hline 17 & $\begin{array}{l}\text { Saya bersedia untuk aktif dengan } \\
\text { kegiatan kelab/persatuan/ sukan/ } \\
\text { permainan. }\end{array}$ & 0.0 & 8.2 & 37.7 & 39.3 & 14.8 & 3.69 & .958 \\
\hline
\end{tabular}




\begin{tabular}{|c|c|c|c|c|c|c|c|c|}
\hline 18 & $\begin{array}{l}\text { Saya berminat untuk terlibat dengan } \\
\text { kegiatan kelab/persatuan/ sukan/ } \\
\text { permainan. }\end{array}$ & 1.6 & 11.5 & 21.3 & 47.5 & 18.0 & 3.61 & .842 \\
\hline 19 & $\begin{array}{l}\text { Saya boleh mengelola aktiviti kelab/ } \\
\text { persatuan/ sukan/permainan. }\end{array}$ & 1.6 & 11.5 & 47.5 & 31.1 & 8.2 & 3.33 & .851 \\
\hline 20 & $\begin{array}{l}\text { Saya boleh memimpin aktiviti kelab/ } \\
\text { persatuan/ sukan/permainan. }\end{array}$ & 3.3 & 11.5 & 47.5 & 32.8 & 4.9 & 3.25 & .850 \\
\hline 21 & $\begin{array}{l}\text { Saya diberi peluang untuk terlibat dengan } \\
\text { kegiatan kelab/persatuan/ sukan/ } \\
\text { permainan. }\end{array}$ & 0.0 & 8.2 & 14.8 & 62.3 & 14.8 & 3.84 & .778 \\
\hline 22 & $\begin{array}{l}\text { Saya aktif terlibat dengan kegiatan kelab/ } \\
\text { persatuan/sukan/ permainan. }\end{array}$ & 1.6 & 8.2 & 39.3 & 45.9 & 4.9 & 3.44 & .786 \\
\hline 23 & $\begin{array}{l}\text { Saya mendapat pengalaman berguna } \\
\text { dengan menyertai aktiviti kelab/ } \\
\text { persatuan/ sukan/ permainan. }\end{array}$ & 0.0 & 3.2 & 9.8 & 68.9 & 18.0 & 4.02 & .645 \\
\hline 24 & $\begin{array}{l}\text { Peribadi dan personaliti saya bertambah } \\
\text { baik setelah terlibat dengan aktiviti kelab/ } \\
\text { persatuan/ sukan/permainan. }\end{array}$ & 0.0 & 1.6 & 21.3 & 54.1 & 23.0 & 3.98 & .719 \\
\hline \multicolumn{9}{|c|}{ Kesedaran pelajar terhadap kepentingan aktiviti fizikal dan bersukan } \\
\hline \multirow[t]{2}{*}{ No. } & \multirow[t]{2}{*}{ Pernyataan } & \multicolumn{5}{|c|}{ Peratusan $(\%)$} & \multirow[t]{2}{*}{ Mean } & \multirow{2}{*}{$\begin{array}{c}\text { Std. } \\
\text { Deviation }\end{array}$} \\
\hline & & STS & TS & TP & $\mathrm{S}$ & SS & & \\
\hline 25 & $\begin{array}{l}\text { Bersukan dapat membantu mengawal } \\
\text { berat badan. }\end{array}$ & 0.0 & 0.0 & 4.9 & 34.4 & 60.7 & 4.56 & .592 \\
\hline 26 & $\begin{array}{l}\text { Bersukan dapat meningkatkan keyakinan } \\
\text { penampilan saya di khalayak. }\end{array}$ & 0.0 & 0.0 & 11.5 & 37.7 & 50.8 & 4.39 & .690 \\
\hline 27 & $\begin{array}{l}\text { Bersukan/aktiviti fizikal penting untuk } \\
\text { kesihatan dan pencegahan penyakit. }\end{array}$ & 0.0 & 0.0 & 1.6 & 34.4 & 63.9 & 4.62 & .522 \\
\hline 28 & Bersukan penting untuk bersosial. & 0.0 & 0.0 & 6.6 & 41.0 & 52.5 & 4.46 & .621 \\
\hline 29 & Bersukan membina personaliti positif. & 0.0 & 0.0 & 3.3 & 47.5 & 49.2 & 4.46 & .565 \\
\hline 30 & $\begin{array}{l}\text { Bersukan dapat meningkatkan daya } \\
\text { tumpuan. }\end{array}$ & 0.0 & 0.0 & 4.9 & 45.9 & 49.2 & 4.44 & .592 \\
\hline 31 & Bersukan melatih merancang strategi. & 0.0 & 0.0 & 9.8 & 45.9 & 44.3 & 4.34 & .655 \\
\hline 32 & $\begin{array}{l}\text { Bersukan dapat meningkatkan prestasi } \\
\text { akademik. }\end{array}$ & 0.0 & 4.9 & 13.1 & 47.5 & 34.4 & 4.11 & .819 \\
\hline \multicolumn{9}{|c|}{ Pengecaman faktor-faktor motivasi dalaman (halangan diri) untuk pelajar bersukan } \\
\hline \multirow[t]{2}{*}{ No. } & Pernyataan & \multicolumn{5}{|c|}{ Peratusan (\%) } & \multirow[t]{2}{*}{ Mean } & \multirow{2}{*}{$\begin{array}{c}\text { Std. } \\
\text { Deviation }\end{array}$} \\
\hline & & STS & TS & TP & $\mathrm{S}$ & SS & & \\
\hline 33 & Bersukan perlukan dorongan. & 0.0 & 6.6 & 23.0 & 31.1 & 39.3 & 4.03 & .948 \\
\hline 34 & $\begin{array}{l}\text { Bersukan perlu dilakukan dalam } \\
\text { kumpulan. }\end{array}$ & 3.3 & 9.8 & 24.6 & 45.9 & 16.4 & 3.62 & .986 \\
\hline 35 & $\begin{array}{l}\text { Bersukan hanya untuk segolongan orang } \\
\text { tertentu. }\end{array}$ & 34.4 & 31.1 & 14.8 & 11.5 & 8.2 & 2.28 & 1.280 \\
\hline 36 & Bersukan perlu diwajibkan. & 1.6 & 9.8 & 24.6 & 29.5 & 34.4 & 3.85 & 1.062 \\
\hline
\end{tabular}

\section{Syed Lamsah bin Syed Chear}

Fakulti Pendidikan dan Sains Sosial,

Universiti Selangor, Selangor, Malaysia 